\title{
In vitro-digested milk proteins: Evaluation of angiotensin-1-converting enzyme inhibitory and antioxidant activities, peptidomic profile, and mucin gene expression in HT29-MTX cells
}

\author{
Carlotta Giromini, ${ }^{1 *}$ Julie A. Lovegrove, ${ }^{2,3}$ David I. Givens, ${ }^{4}$ Raffaella Rebucci, ${ }^{1}$ Luciano Pinotti, ${ }^{1}$ \\ Elisa Maffioli, ${ }^{5}$ Gabriella Tedeschi, ${ }^{5}$ Tamil S. Sundaram, ${ }^{1}$ and Antonella Baldi ${ }^{1}$ \\ ${ }^{1}$ Department of Health, Animal Science and Food Safety, University of Milan, 20133 Italy \\ ${ }^{2}$ Hugh Sinclair Unit of Human Nutrition, Department of Food and Nutritional Sciences, University of Reading, RG6 6AP United Kingdom \\ ${ }^{3}$ Institute for Cardiovascular and Metabolic Research, University of Reading, RG6 6AP United Kingdom \\ ${ }^{4}$ Institute for Food, Nutrition and Health, University of Reading, RG6 6AP United Kingdom \\ ${ }^{5}$ Department of Veterinary Medicine, University of Milan, 20133 Italy
}

\section{ABSTRACT}

Over the past decades, several studies investigated the health-promoting functions of milk peptides. However, to date many hurdles still exist regarding the widespread use of milk-derived bioactive peptides, as they may be degraded during gastrointestinal digestion. Thus, the aim of our study was to in vitro digest intact whey protein isolate (WPI) and casein proteins $(\mathrm{CNP})$, mimicking in vivo digestion, to investigate their bioactive effects and to identify the potential peptides involved. Whey protein isolate and CNP were digested using a pepsin-pancreatin protocol and ultra-filtered (3-kDa cutoff membrane). A permeate $(<3 \mathrm{kDa})$ and a retentate $(>3 \mathrm{kDa})$ were obtained. Soy protein was included as a control (CTR). Angiotensin-1-converting enzyme inhibitory (ACE1-I) and antioxidant activity (AOX) were assessed and compared with those observed in undigested proteins and CTR. Furthermore, the permeate was characterized by nano-liquid chromatography electrospray ionization tandem mass spectrometry (LC-nano ESI MS/MS) using a shotgun peptidomic approach, and retentate was further digested with trypsin and analyzed by MS using a shotgun proteomic approach to identify potentially bioactive peptides. Further, the effects of WPI, CNP, and CTR retentate on cell metabolic activity and on mucus production (MUC5AC and MUC2 gene expression) were assessed in intestinal goblet HT29-MTX-E12 cells. Results showed that WPI permeate induced a significant ACE1-I inhibitory effect $[49.2 \pm 0.64 \%(\mathrm{SEM})]$ compared with undigested WPI, CNP permeate, and retentate or CTR permeate (10.40 $\pm 1.07 \%)$. A significant increase in AOX $(1.58 \pm 0.04$ and $1.61 \pm 0.02 \mu \mathrm{mol}$ of trolox AOX equivalents per

Received April 20, 2019.

Accepted July 16, 2019.

*Corresponding author: carlotta.giromini@unimi.it mg of protein, respectively) upon digestion was found in WPI. Potentially bioactive peptides associated with ACE1-I and antihypertensive effects were identified in WPI permeate and CNP retentate. At specific concentrations, WPI, CNP, and CTR retentate were able to stimulate metabolic activity in HT29-MTX-E12 cells. Expression of $M U C 5 A C$ was increased by CNP retentate and unaltered by WPI retentate; MUC2 expression was significantly increased by $0.33 \mathrm{mg} / \mathrm{g}$ of CNP and reduced by $1.33 \mathrm{mg} / \mathrm{g}$ of CNP. Our results confirm that milk proteins may be rich sources of bioactive compounds, with the greatest beneficial potential of CNP at the intestinal goblet cell level.

Key words: milk protein, in vitro digestion, peptidomics, angiotensin-I-converting enzyme

\section{INTRODUCTION}

Milk proteins are considered among the most important sources of bioactive peptides. Beyond their well-known nutritional values, milk proteins exhibit an extensive range of physiological effects that promote general health and the functions of specific organs and tissues (Meisel and FitzGerald, 2003; MartínezMaqueda et al., 2012b). The most relevant functional properties of milk proteins are obtained following gastrointestinal digestion and milk peptide release (Vermeirssen et al., 2003; Baldi et al., 2005). A recent study compared the peptidome of human jejunal effluents after ingestion of $\mathrm{CN}$ and whey proteins with the peptidome obtained after their in vitro gastrointestinal digestion, allowing the identification of protein domains that are resistant to gastrointestinal digestion (Sanchón et al., 2018). Some of these peptide fragments correspond to previously described sequences that might exert their physiological functions at the intestinal epithelium level or after absorption, where they can elicit unique effects (Shimizu, 2004). It has been reported 
that peptides from the hydrolysis of milk proteins possess functional properties such as antioxidant (AOX) activity, angiotensin-I-converting enzyme inhibitory (ACE1-I) activity, and antimicrobial and cytomodulatory activities (Baldi et al., 2005; Martínez-Maqueda et al., 2012b; Giromini et al., 2017). Petrat-Melin et al. (2015) found that $\beta$-CN variants exhibited AOX and ACE1-I activity upon digestion. Furthermore, larger peptides from the milk protein digestion pool $(>3 \mathrm{kDa})$ are unlikely to reach the bloodstream and will therefore mediate their bioactive effect locally, at the gastrointestinal level (Miner-Williams et al., 2014). For instance, $\beta$-casomorphin 7, a CN-derived peptide, exhibited an enhanced mucin gene expression, mediated by opioid receptors in intestinal goblet cells (Zoghbi et al., 2006). To date, however, most attention has been focused on the bioactive effects of single peptides or hydrolysed proteins (Martínez-Maqueda et al., 2012a; Plaisancié et al., 2015), with limited data on the effect of the whole pool of peptides obtained after in vitro digestion of milk proteins (Mukhopadhya et al., 2015; Volstatova et al., 2016), their potential mechanisms of action, and the candidate peptides involved. Casein and whey proteins, however, are present in milk and dairy products in their intact forms, and the total peptide pool produced from their digestion may have diverse effects in vivo. Evidence from robust in vitro studies simulating protein digestion, and the subsequent evaluation of the bioactive effect, could offer invaluable information on the physiological mechanisms by which these proteins may elicit their biological effects in vivo. Consequently, we investigated the ACE1-I and AOX activity of in vitro digested (permeate and retentate fractions) whey protein isolate (WPI) and casein proteins (CNP) compared with undigested samples and soy protein isolate (CTR). A peptidomic-proteomic analysis of WPI and CNP was also performed, to substantiate the presence of bioactive peptides. Further, the effects of WPI, CNP, and CTR retentate were tested on cell metabolic activity and on mucus production (MUC5AC and MUC2 gene expression) in HT29-MTX-E12 cells, as a human intestinal goblet cell model.

\section{MATERIALS AND METHODS}

\section{Samples and Reagents}

The following samples were tested in this study: WPI (Volac International Ltd., Cambridge, UK) containing $93 \mathrm{~g}$ of protein/100 $\mathrm{g}$ of powder; calcium caseinate (CNP; Garrett Ingredients Ltd., Bristol, UK) containing $90 \mathrm{~g} / 100 \mathrm{~g}$ of powder; and the control soy protein isolate (CTR; MyProtein, Northwich, UK) containing $90 \mathrm{~g} / 100 \mathrm{~g}$ of powder.

\section{In Vitro Digestion}

Whey protein isolate, CNP, and CTR in vitro digestion was performed according to the method of Minekus et al. (2014) and further adapted by our group (Giromini et al., 2017). Briefly, $20 \mathrm{~g}$ of WPI, CNP, or CTR sample were mixed with $150 \mathrm{~mL}$ of distilled $\mathrm{H} 2 \mathrm{O}$ and maintained on an orbital shaker at $150 \mathrm{rpm}$ for 5 min. The digestion procedure involved 3 phases. For the oral phase, $6.66 \mathrm{mg}$ of $\alpha$-amylase in $2.1 \mathrm{~mL}$ of 1 $\mathrm{m} M \mathrm{CaCl} 2, \mathrm{pH} 7$, was added to the samples, and they were incubated for $30 \mathrm{~min}$ at $37^{\circ} \mathrm{C}$ on a shaker. For the gastric phase, the $\mathrm{pH}$ was decreased to 2 with $6 \mathrm{M} \mathrm{HCl}$, and $0.9 \mathrm{~g}$ of pepsin in $8.3 \mathrm{~mL}$ of $0.1 \mathrm{M} \mathrm{HCl}$ was added. The samples were then incubated for $120 \mathrm{~min}$ at $37^{\circ} \mathrm{C}$ on a shaker. For the small intestinal phase, the $\mathrm{pH}$ was increased to 7 with $6 \mathrm{M} \mathrm{NaOH}$, and $0.2 \mathrm{mg}$ of pancreatin and $1.2 \mathrm{~g}$ of bile in NaHCO3 $0.5 \mathrm{M}$ were added to the samples before the final incubation of $180 \mathrm{~min}$ at $37^{\circ} \mathrm{C}$ on a shaker. A blank sample (digestive enzymes alone), a positive control, and a negative control were included as reference samples and for stability tests in all digestions performed $(\mathrm{n}=3)$.

\section{Samples Preparation}

At the end of digestion, the total digesta obtained was transferred to a 3-kDa cutoff membrane (Vivaspin 20, Sartorius, Göttingen, Germany). Each filter was previously activated with $0.1 \%$ BSA solution. Samples were centrifuged for $20 \mathrm{~min}$ at $3,500 \times g\left(5^{\circ} \mathrm{C}\right)$ to obtain permeate (peptides and polypeptides $<3 \mathrm{kDa}$ ) and retentate (peptide and polypeptides $>3 \mathrm{kDa}$ ) fractions. Aliquots from permeate and retentate fractions were sampled and snap frozen in liquid nitrogen to stop enzyme activity, before storing at $-80^{\circ} \mathrm{C}$ for further experiments.

\section{Angiotensin-1-Converting Enzyme Inhibitory Activity}

The ACE1-I of WPI, CNP, and CTR undigested, permeate, and retentate samples was quantified using the ACE1-I assay with furanacroloyl-Phe-Glu-Glu (FAPGG) as the synthetic substrate for the ACE1-I enzyme, as described by Giromini et al. (2017). A synthetic specific ACE inhibitor, captopril, at the concentration of $20 \mathrm{n} M$ was included as control. Data are expressed as percentage of ACE1-I.

\section{Total Antioxidant Capacity: ABTS Assay}

Antioxidant capacity was determined in WPI, CNP, and CTR undigested, permeate, and retentate samples using the method described by Re et al. (1999) with modifications. Trolox stock solution (2.5 $\mathrm{m} M$ in distilled 
water) was used to produce the standard curve. A solution of 2,2'-azinobis (3-ethylbenzothiazoline 6-sulfonic acid (ABTS; $7 \mathrm{mM}$ ) was prepared with potassium persulfate $(140 \mathrm{mM})$ in distilled water and left to react in the dark for 12 to $16 \mathrm{~h}$ to produce the $\mathrm{ABTS}^{\bullet+}$ solution. For the study of AOX capacity of WPI, CNP, and CTR permeates and retentates, the $\mathrm{ABTS}^{\bullet+}$ solution was diluted with PBS, pH 7.4, to reach the absorbance of 0.70 $( \pm 0.02)$ at $734 \mathrm{~nm}$, and equilibrated at $30^{\circ} \mathrm{C}$. A volume of $20 \mu \mathrm{L}$ of sample or trolox standard was mixed with $2 \mathrm{~mL}$ of $\mathrm{ABTS}^{\circ+}$ working solution and incubated in dark for 6 min at room temperature before measuring absorbance at $734 \mathrm{~nm}$ on the spectrophotometer. Appropriate solvent blanks were included in each assay. The percentage inhibition of absorbance at $734 \mathrm{~nm}$ was calculated and plotted as a function of concentration of samples and of trolox for the standard reference data. The AOX results are expressed as micromole of trolox equivalent per milligram of protein.

\section{Proteomic and Peptidomic Profiles}

Permeate and retentate of WPI and CNP were analyzed by nano-liquid chromatography (LC-nano) electrospray ionization tandem mass spectroscopy (ESI MS/MS), using a shotgun label-free approach, to identify peptides and proteins. The permeate was analyzed without any digestion before MS/MS to identify endogenous peptides presents in the samples, the so-called peptidomic strategy (Aletti et al., 2016; Figure 1), and the retentate was further digested using sequence-grade trypsin with a protein:protease ratio of 20:1 (Iametti et al., 2001) in a proteomic strategy (Figure 1). Digestion with trypsin is a normal procedure in the proteomic MS/MS analysis, to identify proteins based on the sequence of the corresponding tryptic peptides. Trypsin generates experimentally observable peptides that can be used to uniquely identify a protein.

Mass analysis was carried out using an LTQ Orbitrap Velos (Thermo Fisher Scientific, Bremen, Germany), as described in Maffioli et al. (2017) for the peptidomic strategy and in Coccetti et al. (2008) for the proteomic analysis.

\section{Peptidomic and Proteomic Data Analysis}

The spectra derived from MS analysis were compared against the National Center for Biotechnology Information (NCBI) mammalian sequence database, for CN and whey samples (release 24.01.2017), by the Sequest search engine contained in the Proteome Discoverer 1.4.0 software (Thermo Fisher Scientific). The following parameters were used: $10 \mathrm{ppm}$ for MS and $0.5 \mathrm{Da}$ for MS/MS tolerance; Met oxidation, N-terminal acety- lation, and Gln/Asn deamidation as variable modifications. We further added carbamidomethylation of Cys as fixed modification and trypsin (2 misses) as protease as parameters in the proteomic analysis. Only peptides with false discovery rate $1 \%$ (against decoy) and cross-correlation value 1.5 were included for positive identification (Dell'Orco et al., 2016). Two replicates were carried out for each sample in the MS analysis. All peptides were searched in SATPdb (Singh et al., 2016) and BIOPEP-UWM database (Minkiewicz et al. 2008), 2 databases of structurally annotated therapeutic peptides, to find potentially bioactive peptides. To consider possible further proteolysis, the search was performed keeping a minimum sequence length of 6 amino acids and applying an "IF" nested function to a matrix that compared the sequence of each peptide found with those of the database (Microsoft Excel 2016, version 15.27; Microsoft Corp., Redmond, WA). The MS proteomics data have been deposited to the ProteomeXchange Consortium via the PRIDE partner repository (Vizcaino et al. 2016), with the data set identifier PXD012588 for the permeate and PXD012625 for the retentate.

\section{Cell Culture Experiments}

In our study, the permeate and retentate fractions obtained after in vitro digestion reproduced the pool of peptides generated during physiological digestion in humans (Giromini et al., 2019). Small peptides $(<3 \mathrm{kDa}$, permeate fraction) could be absorbed by epithelial cells along the small intestine and enter blood circulation, whereas polypeptides ( $>3 \mathrm{kDa}$, retentate fraction) can reach the colonic environment. Thus, in a second set of experiments, we tested the effects of WPI, CNP, and CTR retentate fractions on intestinal HT29-MTX-E12 cell metabolic activity and mucus production modulation.

\section{Metabolic Activity}

The HT29-MTX-E12 cells used for this experiment were kindly donated by Stig Purup, Aarhus University, Research Centre Foulum, Denmark. This human colorectal adenocarcinoma cell line, a clone of HT29 cells, is able to differentiate into a mucus-producing goblet-like cell line. Cell maintenance was performed in $25-\mathrm{cm}^{2}$ flasks using $15 \mathrm{~mL}$ of Dulbecco's modified Eagle's medium (DMEM) with glucose $(4.5 \mathrm{~g} / \mathrm{L})$ and supplemented with $10 \%$ fetal calf serum (FCS), $1 \% 1$ $M$ HEPES, $1 \%$ (vol/vol) penicillin/streptomycin, $2 \%$ Glutamax (Euroclone, Milan, Italy), and 1\% minimum essential medium (MEM) NEAA. Cells were cultivated at $37^{\circ} \mathrm{C}$ in a humidified incubator with $5 \% \mathrm{CO}_{2}$. All experiments were performed using HT29-MTX-E12 cells 
within 6 cell passages (passages 40 to 45), to ensure reproducibility.

Undifferentiated HT29-MTX-E12 cells were plated at a density of $1.5 \times 10^{4}$ cells/well in 96-well plates and cultured for $24 \mathrm{~h}$. Whey protein isolate, CNP, and CTR retentates were diluted in $0.05 \%$ FCS DMEM (Giromini et al., 2015) and added to the cell culture at different concentrations (from 42.62 to $0.16 \mathrm{mg} / \mathrm{mL}$ ). For control wells, $0.05 \%$ FCS DMEM was added.

The retentate stock solutions of WPI, CNP, and CTR contained between 86.23 and $85.24 \mathrm{mg}$ protein/ $\mathrm{mL}$. Stock solutions were normalized to $85.24 \mathrm{mg} / \mathrm{mL}$, which corresponds to the lowest protein concentration observed among WPI, CNP, and CTR. Considering the high cytotoxicity of stock solutions and the absence of DMEM medium to regulate the osmotic pressure, we

PROTEOMIC APPROACH

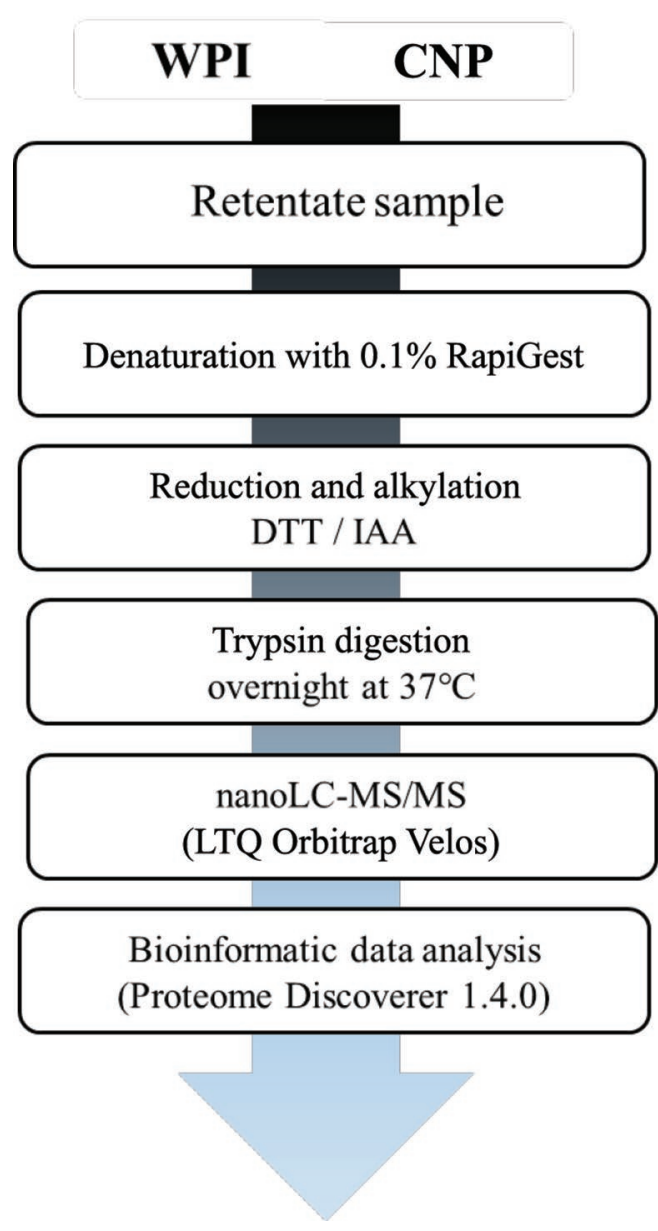

tested diluted concentrations of retentate from 42.62 up to $0.16 \mathrm{mg} / \mathrm{mL}$.

After 3 and $24 \mathrm{~h}$ of treatment, the metabolic activity of HT29-MTX-E12 cells was evaluated by MTT [3-(4,5-dimethylthiazol-2-yl)-2,5 diphenyltetrazolium bromide] assay, which measures production of the chromophore formazan, which is produced in viable cells by the mitochondrial enzyme succinate dehydrogenase. Three replicates per treatment were included, and the experiments were repeated 3 times $(n=3)$. Specifically, the cell metabolic activity percentage induced by the protein retentate was calculated as follows:

$\%$ cell metabolic activity $=$

(mean optical density of treated cells/

mean optical density of control cells) $\times 100$.

\section{PEPTIDOMICAPPROACH}

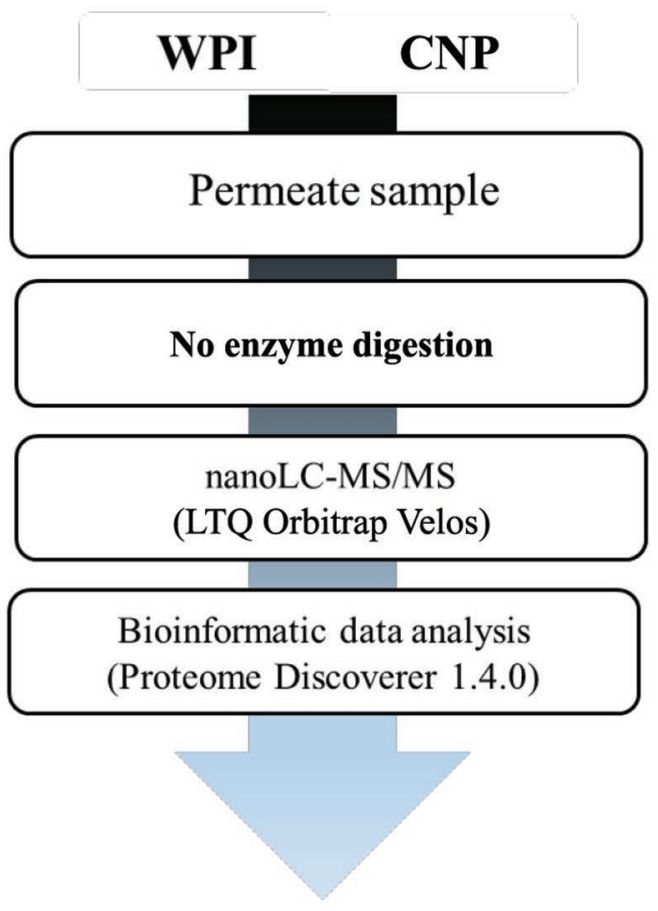

Figure 1. Peptidomic and proteomic workflow on casein (CNP) and whey (WPI) proteins. Retentates and permeates were analyzed by liquid chromatography (LC) tandem mass spectroscopy (MS/MS) using an LTQ Orbitrap Velos (Thermo Fisher Scientific, Bremen, Germany) and searched against the National Center for Biotechnology Information (NCBI) mammalia sequence database (casein and whey samples) and UniProt glycine max (soy samples) by Sequest (Proteome Discoverer 1.4.0 software, Thermo Fisher Scientific). DTT $=$ dithiothreitol; IAA $=$ iodoacetamide. RapiGest: Waters Corp., Milford, MA. 


\section{Mucus Production: Real-Time Quantitative PCR}

The HT29-MTX-E12 cells were seeded at a density of $5 \times 10^{5}$ cells/well in 12-well plates and maintained for up to $21 \mathrm{~d}$ in complete medium (Martínez-Maqueda et al., 2012a). Martínez-Maqueda and colleagues (2012a) reported that, after $21 \mathrm{~d}$ of culture, HT29-MTX-E12 cells express a stable amount of mucus. At d 21, the cells were washed with PBS, and the medium was replaced with $0.05 \%$ FCS DMEM medium for $24 \mathrm{~h}$ (cell starvation). The treatment medium $(0.05 \%$ FCS $)$ with WPI, CNP, or CTR protein retentate at different concentrations (0.33 up to $1.33 \mathrm{mg} / \mathrm{g}$ ) was added to the cells, which were then incubated in a controlled atmosphere $\left(37^{\circ} \mathrm{C} / 5 \% \mathrm{CO}_{2}\right)$ for $3 \mathrm{~h}$. The concentration range was chosen based on the MTT test results. Control cells (0 mg/g) were not treated.

Real-time quantitative PCR (qRT-PCR) assay was carried out using the real-time fluorescence method with a Strategene Mx3000p (Agilent Technologies, La Jolla, CA). At the end of 3-h incubation, total RNA was extracted from the HT29-MTX-E12 cells using a NucleoSpin RNA II kit (Macherey-Nagel, Duren, Germany) according to the manufacturer's protocol. The RNA (50 ng) was reverse-transcribed using the iScript cDNA synthesis kit (Bio-Rad, Hercules, CA), and the resulting cDNA was used as a template for qRT-PCR. The MUC5AC and MUC2 genes were amplified by qRT-PCR with primer sequences previously published by Martínez-Maqueda et al.(2012a) and Nielsen et al.(2018) (Table 1), and cyclophilin and $\beta$-actin were included as a reference genes. The primers were checked for specificity in BLAST (www.ncbi.nlm.nih.gov/ BLAST/) before the qRT-PCR experiments.

Each reaction tube contained $2 \times$ SYBR Green realtime PCR Master Mix (Bioline, London, UK), genespecific forward and reverse primers, and cDNA $(1 \mu \mathrm{L})$. The master mix included Maxima Hot Start Taq DNA polymerase (Bioline), deoxynucleoside triphosphate (dNTP) in an optimized PCR buffer, and SYBR Green I dye supplemented with ROX passive reference dye (Bioline). All reactions were analyzed under the same conditions and normalized to the ROX reference dye to correct eventual fluctuations in the readings due to evaporation phenomena. The samples were tested in triplicate, and non-reverse-transcribed controls and no-template controls were included in the assays. The thermal profile began with $4 \min$ at $95^{\circ} \mathrm{C}$, followed by 40 cycles of $95^{\circ} \mathrm{C}$ for $30 \mathrm{~s}$ and $60^{\circ} \mathrm{C}$ for $1 \mathrm{~min}$. Relative quantification was performed, and values were normalized to the internal reference gene cyclophilin. Two internal controls, cyclophilin and $\beta$-actin genes, were tested as endogenous genes, and cyclophilin was selected because its amplification was more efficient and it had no variation across treatments. This verified the efficiency of its use as the endogenous control.

\section{Statistical Analysis}

Statistical analysis was performed using the GraphPad Prism version 8 software package (GraphPad Software, San Diego, CA). Data are presented as least squares means (LSM) \pm standard error of the mean (SEM). The ACE1-I and AOX data were analyzed using a 2-way ANOVA to identify the significant differences between undigested, permeate, and retentate samples in WPI, CNP, and CTR. The differences between means were compared using Tukey's test and considered statistically significant at $P<0.05$. For gene expression analysis, the comparative CT method was used (Livak and Schmittgen, 2001) to determine the fold changes in gene expression, calculated with the threshold method (2- $\Delta \Delta \mathrm{CT})$. A 2-way ANOVA was also performed on cell metabolic activity and gene expression data, and means were compared using Tukey's test $(P<0.05)$.

\section{RESULTS}

\section{In Vitro Digestion}

Samples of WPI, CNP, and CTR were in vitro digested, and total digesta was filtered with a $3-\mathrm{kDa}$ membrane to obtain permeate $(<3 \mathrm{kDa})$ and retentate $(>3 \mathrm{kDa})$ fractions. The WPI, CNP, and CTR permeate fractions were further tested for ACE1-I and AOX activities. The WPI, CNP, and CTR retentate fractions

Table 1. Primer sequences used for quantitative real-time PCR; quantification by SYBR Green (Bioline, London, UK) was used for all genes

\begin{tabular}{|c|c|c|}
\hline Gene (length) & Primer & Reference \\
\hline Mucin $2(M U C 2 ; 259 \mathrm{bp})$ & $\begin{array}{l}\text { 5'-ACCCCAAGCCCTTCTACGAG-3' } \\
\text { 3'-GAGTGGATGCCGTTGATGGT-5' }\end{array}$ & Nielsen et al., 2018 \\
\hline$\beta$-Actin (197 bp) & $\begin{array}{l}\text { 5'-CTTCCTGGGCATGGAGTC-3' } \\
\text { 3'-GCAATGATCTTGATCTTCATTGTG-5' }\end{array}$ & Martínez-Maqueda et al., 2012a \\
\hline Cyclophilin (160 bp) & $\begin{array}{l}\text { 5'-CTTCCTGGGCATGGAGTC-3' } \\
\text { 3'-GCAATGATCTTGATCTTCATTGTG-5' }\end{array}$ & Martínez-Maqueda et al., 2012a \\
\hline
\end{tabular}




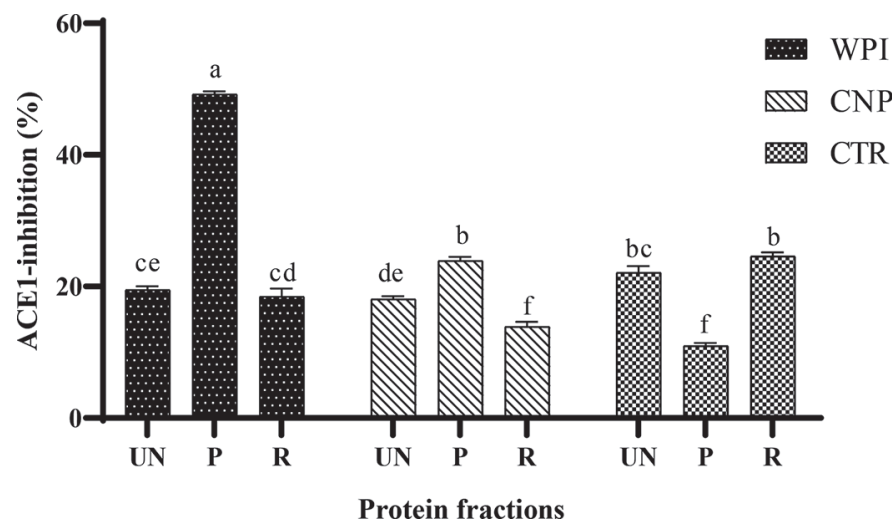

Figure 2. Angiotensin-1-converting enzyme inhibitory (ACE1-I) effects of undigested protein (UN) and permeates $(\mathrm{P})$ and retentates $(\mathrm{R})$ of whey protein isolate (WPI), casein protein (CNP), and soy (CTR). Data are normalized on the nitrogen content of each sample and are expressed as percentage of ACE1-I. The synthetic ACE inhibitor captopril at the concentration of $20 \mathrm{n} M$, included as control, inhibited $97 \%$ of enzyme activity. Data are expressed as LSM \pm SEM. Different lowercase letters $(\mathrm{a}-\mathrm{f})$ denote significant differences $(P<$ $0.05)$.

were tested for ACE1-I, AOX, and cytomodulatory effect. A peptidomic-proteomic characterization was performed on WPI and CNP permeates and retentates, to check the presence of bioactive peptides.

\section{Angiotensin-1-Converting Enzyme Inhibitory Activity}

The highest ACE1-I effect occurred in WPI permeate (Figure 2). In particular, WPI permeate induced a significant ACE1-I inhibitory effect $(49.2 \pm 0.64 \%)$ compared with WPI undigested $(P<0.001)$, CNP permeate $(P<0.001)$, CNP retentate $(P<0.001)$, and CTR permeate $(10.40 \pm 1.07 \% ; P<0.001)$. The CNP permeate induced a significant ACE1-I effect (23.91 $\pm 0.64 \%)$ compared with CTR permeate $(P<0.001)$, which showed the lowest ACE1-I effect.

\section{Total Antioxidant Capacity: ABTS Assay}

Permeates of WPI and CNP showed significant increases in AOX $[1.58 \pm 0.04$ and $1.61 \pm 0.02 \mu \mathrm{mol}$ trolox AOX equivalents/mg protein (TrAOX Eq/ mg PRT), respectively], compared with undigested WPI and CNP $(<0.6 \mu \mathrm{mol}$ TrAOX equ/mg PRT; $P=0.02)$, CTR permeate $(1.07 \pm 0.04 \mu \mathrm{mol}$ TrAOX equ $/ \mathrm{mg}$ PRT; $P=0.04$ ), and WPI, CNP, and CTR retentates. Low AOX was observed in CTR retentate $(<0.6 \mu \mathrm{mol}$ TrAOX equ/mg PRT).

\section{Proteomic-Peptidomic Analysis of Digesta}

Based on the results obtained with ACE1-I and AOX activities, WPI and CNP permeate and retentate samples were analyzed for their peptide contents. Permeate was characterized by LC-nano ESI MS/MS using a shotgun peptidomic approach, and retentate was further digested with trypsin and analyzed by MS with a shotgun proteomic approach, as shown in Figure 1. The list of peptides identified in the retentates and permeates of WPI and CNP are reported in Supplemental Tables S1 (permeate) and S2 (retentate), respectively (https://doi.org/10.3168/jds.2019-16833). All data sets from CNP and WPI were searched in SATPdb and BIOPEP-UWM databases, taking into account possible further proteolysis to find potentially bioactive peptides. In accordance with the results reported above, peptides with ace-inhibitory and antihypertensive activity were identified in the WPI permeate, together with one peptide with antihypertensive properties in the $\mathrm{CN}$ retentate (TPEVDDEALE; Table 2).

\section{Cell Culture Experiments}

In our study, the retentate fraction contained molecules with a molecular size larger than $3 \mathrm{kDa}$. These

Table 2. List of antihypertensive and angiotensin-1-converting enzyme (ACE)-inhibitory peptides found in whey protein isolate (WPI) and casein protein $(\mathrm{CNP})$ permeate and retentate samples

\begin{tabular}{llll}
\hline Item & Database $^{1}$ & Permeate & Retentate \\
\hline CNP & TPEVDDEALE & & TPEVDDEALEK \\
Antihypertensive & TPEVDDEALE & & TPEVDDEALEKFDK \\
WPI & IDALNENK & KIDALNENKVLVLDTDYK & KIDALNENKVLVLDTDYK \\
Antihypertensive & VLDTDYK & VEELKPTPEGNLE \\
& VEPTPEGN & VEELKPTPEGNLE & VYVEELKPTPEGNLE \\
& LKPTPEGN & VYVEELKPTPEGNLE & \\
& VEELKP & VYVEELKPTPEGNLE & \\
ACE inhibitory & VLDTDYK & KIDALNENKVLVLDTDYK & \\
\hline
\end{tabular}

\footnotetext{
${ }^{1}$ Peptide databases: SATPdb (Singh et al., 2016) and BIOPEP-UWM (Minkiewicz et al., 2008).
} 
molecules can reach the colonic tissue and, ideally, can escape small intestinal absorption. There is little evidence that dietary bioactive peptides other than di- and tripeptides, can cross the gut wall and enter blood circulation. Whereas di- and tripeptides can be absorbed by selective transport systems (such as paracellular pathways via tight junctions, passive diffusion via enterocytes, endocytosis, or carrier-mediated transport systems), larger peptides and protein particulates may cross the gut wall, although only in very small quantities (Miner-Williams et al., 2014). Therefore, we selected the $>3-\mathrm{kDa}$ retentate fraction for colon cell experiments.

The results presented here indicated that all of the protein fractions, at specific concentrations, were able to modulate the metabolic activity of HT29-MTX-E12 cells and to exert trophic effects on intestinal epithelia. Treatment of the HT29-MTX-E12 cell monolayer with WPI, CNP, and CTR (soy protein isolate) retentates stimulated or reduced cell metabolic activity depending on the dosage, as measured by MTT test of mitochondrial activity. As shown in Figure 3, in the lowest range of concentrations tested (0.16 to $1.33 \mathrm{mg} / \mathrm{g}$ ), CTR retentate significantly enhanced HT29-MTX-E12 cell metabolic activity compared with untreated cells $(0 \mathrm{mg} / \mathrm{g})$. In particular, after $24 \mathrm{~h}, \mathrm{CTR}$ retentate at concentrations from 0.16 to $0.66 \mathrm{mg} / \mathrm{g}$ significantly enhanced cell metabolic activity $(P<0.01)$. After 24-h treatment, CNP at concentrations of 0.33 and $0.66 \mathrm{mg} / \mathrm{g}$ increased cell metabolic activity compared with untreated cells $(P<0.05)$, whereas after $3 \mathrm{~h}$ of $\mathrm{CNP}$ and WPI, and after $24 \mathrm{~h}$ of WPI treatment, cell metabolic activity remained unchanged compared with untreated cells $(0 \mathrm{mg} / \mathrm{g})$. Considering the highest concentration range (2.66 to $21.31 \mathrm{mg} / \mathrm{g}$ ), we observed that WPI, CNP, and CTR retentates reduced the metabolic activity of HT29-MTX-E12 cells in a dose-dependent manner. In contrast, after 3-h treatment with CTR retentate at concentration from 2.66 to $21.31 \mathrm{mg} / \mathrm{g}$, cell metabolic activity was unaltered compared with untreated cells $(0 \mathrm{mg} / \mathrm{g})$.

\section{MUC2 and MUC5AC Gene Expression}

We cultured HT29-MTX-E12 cells for $3 \mathrm{~h}$ in the presence of WPI, CNP, or CTR retentates. Specific concentrations of CNP retentate modulated the expression of mucins MUC5AC and MUC2 in HT29-MTX-E12 cells. In particular, CNP retentate promoted the expression of $M U C 5 A C \mathrm{mRNA}$ at $0.33 \mathrm{mg} / \mathrm{g}(P=0.02), 0.66$ $\mathrm{mg} / \mathrm{g}(P=0.04)$, and $1.33 \mathrm{mg} / \mathrm{g}(P=0.008)$ compared with untreated cells $(0 \mathrm{mg} / \mathrm{g})$ and with WPI and CTR (Figure 4). Expression of MUC5AC mRNA remained unaltered $(P>0.1)$ by WPI and CTR retentate treat- ments. At the concentration of $0.33 \mathrm{mg} / \mathrm{g}$, CNP retentate also promoted the expression of MUC2 mRNA. The MUC2 mRNA gene expression with treatment by WPI and CTR retentates remained unaltered.

\section{DISCUSSION}

In the present study we digested WPI, CNP and soy (CTR) proteins in vitro to assess their ACE1-I and AOX activities and to study the release of bioactive peptides. We found that permeate and, to a lesser extent, retentate of WPI showed significant ACE1-I activity compared with undigested WPI, demonstrating that in vitro digestion influenced the liberation of ACE1-I peptides. Furthermore, the permeate fraction of CNP also showed higher ACE1-I activity after digestion, confirming the results reported in our previous study, in which ACE1-I activity was tested on a panel of dairy and plant protein supplements (Giromini et al., 2017), and in the study of Petrat-Melin et al. (2015). In the CTR sample, ACE1-I activity was significantly reduced by the permeate fraction compared with CTR undigested. For peptides to be effective ACE1 inhibitors, they must resist digestion and enter circulation before reaching the target organ. Therefore, the bioactivities observed in vitro may not directly translate into significant effects in vivo, due to the differential bioavailability of peptides in different individuals. The heterogeneity of individuals' responsiveness to protein consumption can prevent identification of the associations between dietary intake and health, hinder identification of health benefits for specific population groups, and limit our understanding of the exact roles of different bioactive compounds. Moreover, the absorption step in the gastrointestinal environment represents a key point in dairy peptide bioactivity. In order for bioactive peptides to exert ACE1-I effects after oral administration, they must remain intact and active after intestinal transport and contact with brush-border peptidases.

As reported by Miner-Williams et al. (2014), only a few of the large number of milk peptides with proven antihypertensive activity in vitro have so far proven to be clinically effective in vivo. However, our recent studies (Fekete et al., 2016a,b, 2018) demonstrated a relationship between blood pressure reduction in humans as a result of chronic and acute consumption of milk protein-based supplements and their in vitro ACE1-I activity. Those studies demonstrated a significant decrease in blood pressure in both whey and CN protein-consumer groups, compared with the control group (no protein) in a double-blind crossover randomized controlled trial. The results reported in the present study further support the aforementioned outcomes. 
A

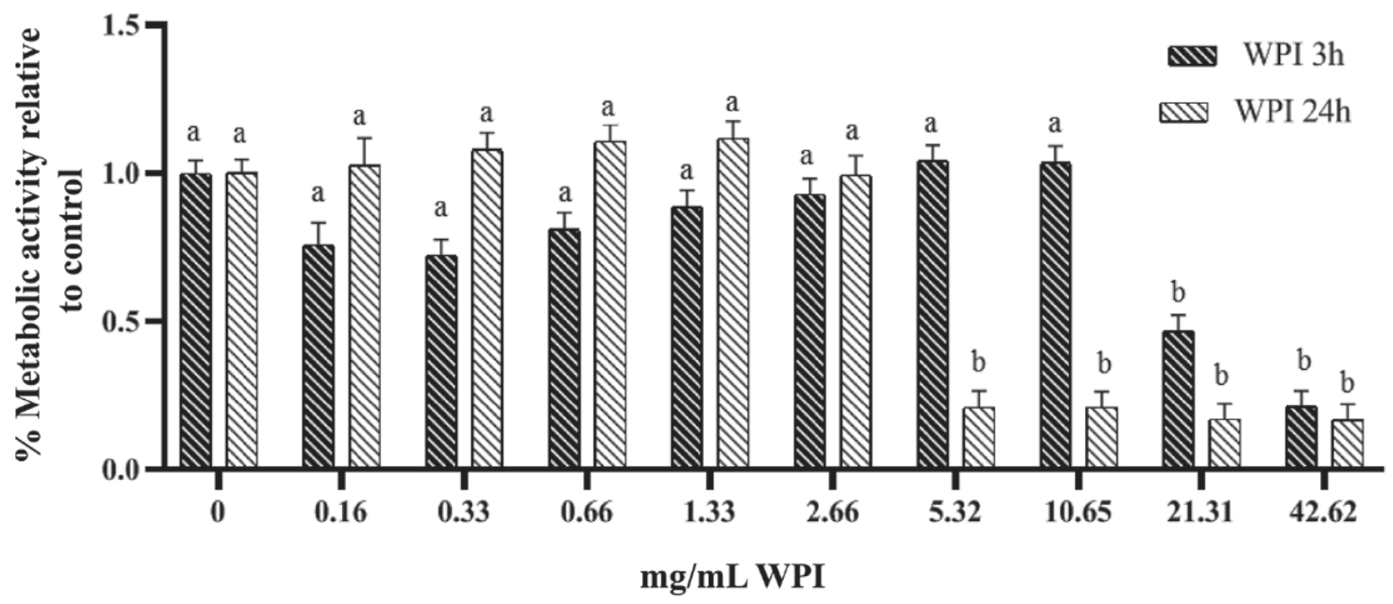

B
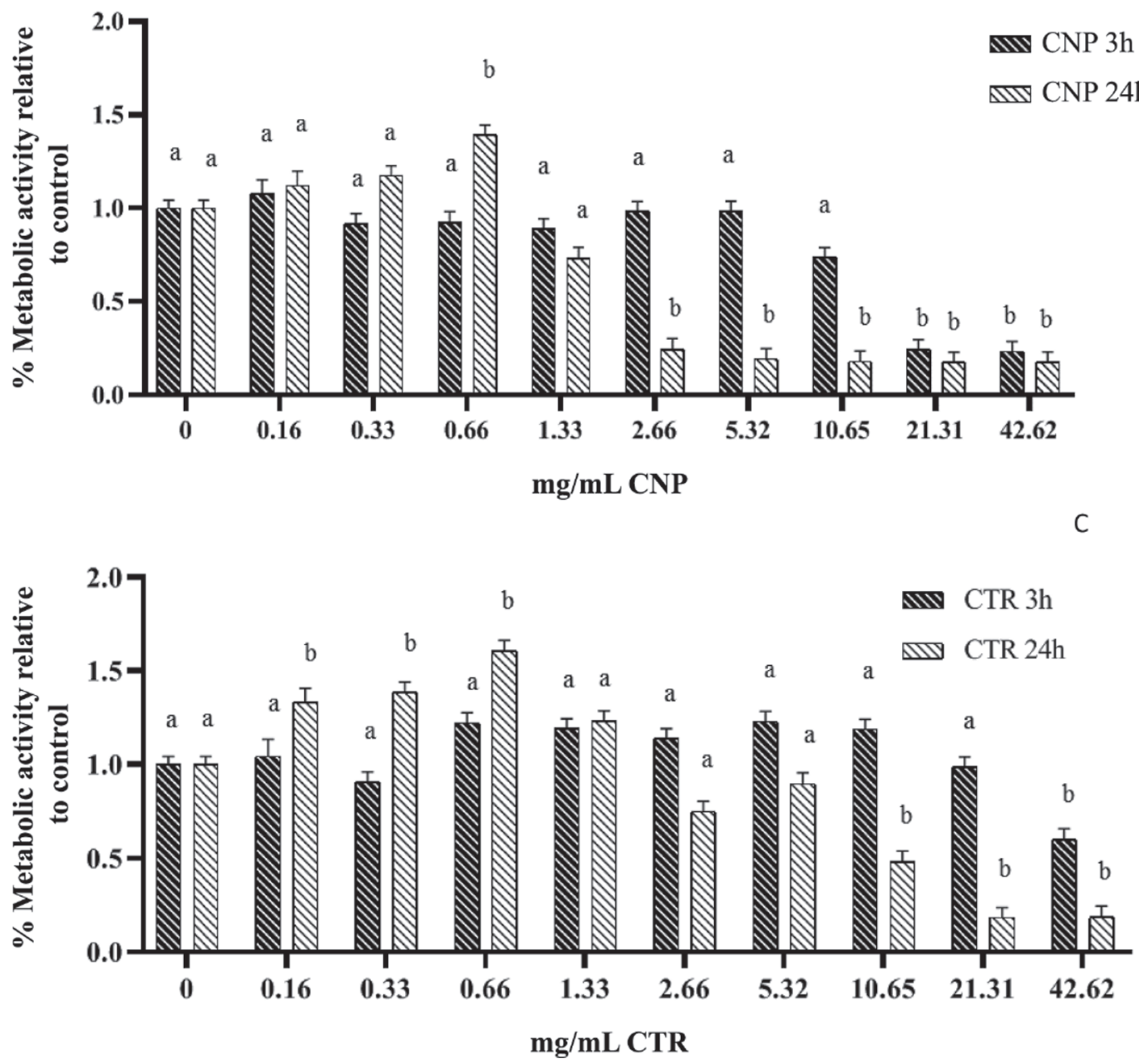

Figure 3. Effects of (A) whey protein isolate retentate (WPI), (B) casein protein retentate (CNP), and (C) soy retentate (CTR) on HT29MTX-E12 cell metabolic activity (expressed as cell viability) after 3 and $24 \mathrm{~h}$ of treatment. Data are expressed as LSM \pm SEM. Different lowercase letters $(\mathrm{a}, \mathrm{b})$ denote significant differences from the metabolic activity obtained in the control cells $(0 \mathrm{mg} / \mathrm{mL} ; P<0.05)$. 
In the present study, in vitro digestion significantly enhanced AOX capacity of WPI, CNP, and CTR, as evaluated by ABTS assay. In our experimental conditions, CNP permeate and, to a lesser extent, WPI permeate showed higher AOX properties compared with CTR. Caseins have high contents of AOX amino acids, such as tyrosine and tryptophan, the oxidation of which may quench free radicals, inducing AOX effects (Clausen et al., 2009). Clausen et al. (2009) also reported that $\mathrm{CN}$ are the highest radical scavengers in milk. Di Pierro et al. (2014) reported that the AOX capacity values for sodium caseinate increased from 0.06 to $0.18 \mu \mathrm{mol}$ trolox equivalents/mg protein, and for $\beta$-CN from 0.51 to $1.19 \mu \mathrm{mol}$ trolox equivalents $/ \mathrm{mg}$ protein, after enzymatic hydrolysis. Petrat-Melin and co-authors (2015) assessed the AOX of in vitro digested $\beta-\mathrm{CN}$ variants and reported a significant increase in
AOX capacity upon digestion. The AOX capacities exhibited by the permeates of WPI, CNP, and CTR in this study support the claim that food proteins are a natural source of AOX compounds. The distinct AOX properties of our samples may be attributable to the specificity of the peptides or amino acids released from WPI, CNP, and CTR primary sequences.

Based on ACE1-I and AOX activity results, we further analyzed WPI and CNP permeates and retentates for their bioactive peptide content. In accordance with the results reported above, peptides with ACE1-I and antihypertensive activity were identified in the WPI permeate, together with one peptide with antihypertensive property in the CNP retentate. Only a few previous studies, such as those conducted by PetratMelin and co-authors (2015), have assessed the release of bioactive peptides after digestion. Presently there is

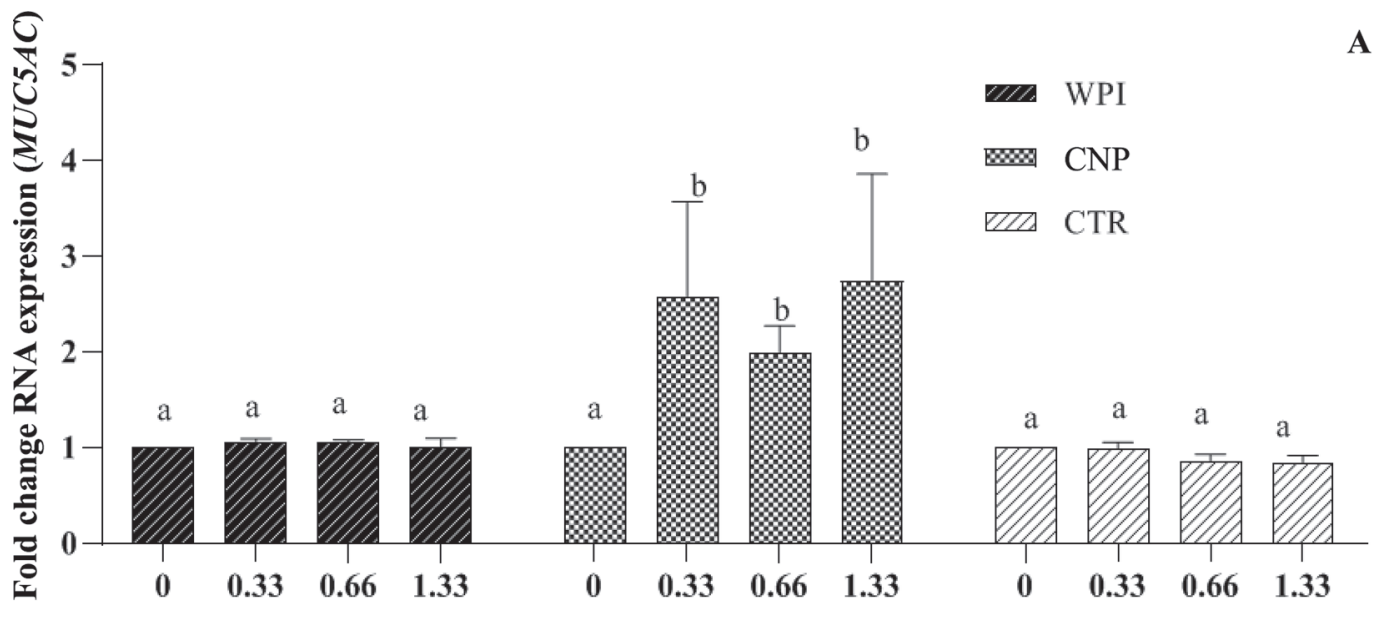

$\mathrm{mg}$ protein / $\mathrm{mL}$ retentate

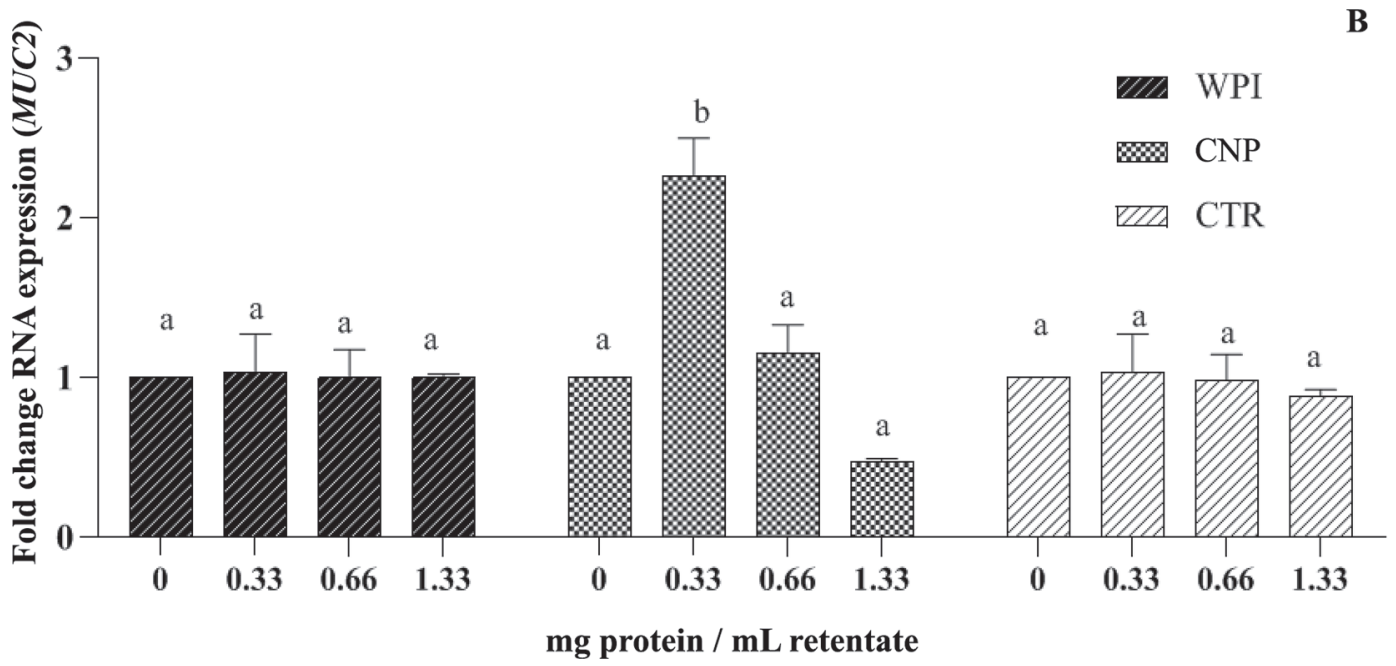

Figure 4. Effects of 3-h treatment with whey protein isolate (WPI), casein protein (CNP), and soy (CTR) retentates on (A) MUC5AC and (B) MUC2 gene expression in HT29-MTX-E12 cells (concentrations range from 0.33 to $1.33 \mathrm{mg} / \mathrm{g}$ ), determined by quantitative real-time PCR Data are expressed as gene expression levels relative to the controls (untreated cells, $0 \mathrm{mg} / \mathrm{g}$ ). Different lowercase letters (a, b) denote significant differences $(P<0.05)$. Data are expressed as means LSM \pm SEM. 
a lack of information about the comparison between protein bioactivity and the effective release of peptides associated with that bioactivity. Therefore, the present study compared the biological activities of digested proteins with the identification of bioactive peptides. Altogether, our data confirm that WPI is a rich source of ACE1-I peptides, with tested bioactivity produced upon digestion. Casein protein permeate showed significant ACE1-I activity upon digestion, although no bioactive peptides associated with this activity have been found in the permeate. With regard to AOX capacity, although we observed a significant increase after protein digestion, we did not identify peptides associated with this bioactivity. This may be due to analytical limitations associated with MS peptide identification, as our method allowed for the identification of 6 or more amino acids; thus shorter peptides or single amino acids may not have been identified.

A step forward in peptidomic analysis will be to test ACE1-I peptides from WPI and CNP for their absorption capacity and for their ability to preserve their bioactivity after absorption and cell internalization. This will massively help in the design of nutritional strategies to prevent cardiovascular disease or to standardize the industrial production of ACE1-I peptides obtained by enzymatic hydrolysis.

In our study, the retentate fraction contained molecules with a molecular size larger than $3 \mathrm{kDa}$; these molecules can ideally escape absorption in the small intestine and reach the colonic tissue. There is little evidence that dietary bioactive peptides other than diand tripeptides can cross the gut wall and enter blood circulation. Whereas di- and tripeptides can be absorbed by selective transport systems (such as paracellular pathways via tight junctions, passive diffusion via enterocytes, endocytosis, or carrier-mediated transport systems), larger peptides and protein particulates may cross the gut wall only in very small quantities (MinerWilliams et al., 2014). This is why we selected the $>3$ $\mathrm{kDa}$ retentate fraction for colon cell experiments.

At the lowest range of concentrations, WPI, CNP, and CTR retentates maintained or stimulated the metabolic activity of undifferentiated HT29-MTXE12 intestinal cells, whereas the highest range of concentrations reduced cell metabolic activity. Several food-derived peptides have been described as exerting potential chemopreventative properties against the viability of malignant cells (Meisel and FitzGerald, 2003; Fernández-Tomé et al., 2018). In this respect, the inhibitory role that we detected may be interesting, because HT29-MTX-E12 cells have a cancerous origin.

Moreover, we observed a hormetic effect induced by CTR retentate (for 3 - and 24-h treatments) and, to a lesser extent, by CNP retentate (for 24-h treatment) in HT29-MTX-E12 cells. The hormetic response is a biological phenomenon whereby a stimulatory effect results from exposure to low doses of a compound that is inhibitory when given to a cell at higher doses (Calabrese and Baldwin, 2002; Purup and Nielsen, 2012).

In general, in vitro cell-based models represent an effective tool to test nutritional ingredients for food and feed evaluation (Cheli et al., 2015; Giromini et al., 2016; Fusi et al., 2018). Cell culture studies have provided increasing evidence that milk-derived bioactive peptides modulate metabolic activity, differentiation, and apoptosis of different cell types (Hartmann and Meisel, 2007). Pecorini and co-authors (2009) demonstrated that lactoferrin could be involved in regulating the growth of both intestinal and mammary epithelial cells. Purup et al. (2007) showed that whey fractions from bovine milk stimulated intestinal cell growth. Meisel and FitzGerald (2003) hypothesized that milk peptides can cooperatively stimulate the viability of intestinal cells and, thus, the development of the digestive tract. In a recent study, Purup and co-authors (2018) demonstrated that both CN- and whey-based supplements exerted proliferative effects on intestinal cells, in agreement with our study. Tonolo et al. (2018) have reported the ability of milk peptides to increase cell proliferation. In general, cell proliferation is an essential mechanism for the re-establishment of surface epithelium after injury, and food proteins may have an important role in prevention of epithelium damage and in the recovery of gut tissue integrity. However, whether the herein-observed effect on cell metabolic activity is the result of individual peptide activity or of the synergistic activity of a peptide pool produced by in vitro digestion is presently not known and requires further investigations.

In our study, CNP was able to significantly promote the expression of the MUC5AC gene at all concentrations tested in mucus-producing HT29-MTX-E12 cells ( $21 \mathrm{~d}$ of culture). Our results show a relationship of the effect of CNP to dose: at the highest concentrations tested, CNP reduced MUC2 expression, but at the lowest concentration tested, CNP significantly improved MUC2 expression. Our results are in agreement with those of previous studies that have demonstrated the role of milk peptides in the modulation of gastrointestinal mucus production. Plaisancié et al. (2013) demonstrated that the total peptide pool from yogurt modulated cell proliferation and the secretion of mucins in HT29-MTX-E12 cells. Martínez-Maqueda et al. (2013) reported that CN hydrolysate stimulates HT29-MTXE12 cells and promotes the expression of MUC5AC. The same group demonstrated the mucin-secreting role of whey protein hydrolysate in HT29-MTX-E12 cells: $\beta$-lactorphin increased the synthesis of mucin proteins 
without eliciting differences in MUC5AC gene expression (Martínez-Maqueda et al., 2012a). Plaisancié et al. (2015) demonstrated an increase in mucin secretion and MUC2 and MUC4 gene expression in HT29-MTX-E12. $\beta$-Casomorphin-7 increases MUC5AC mRNA expression and the secretion of this mucin, as demonstrated by Zoghbi et al. (2006). $\alpha$-Lactorphin, a whey-derived peptide, showed enhanced expression of the MUC5AC gene in HT29-MTX-E12 cells (Martínez-Maqueda et al., 2012a).

The main limitation of our gene expression analysis is that we did not observe a mucin secretion effect, which may precede gene expression stimulation (Martínez-Maqueda et al., 2013) in the process of replenishing the intracellular mucin pool of goblet cells. This latter point requires further analysis. Overall, the proliferative and gene expression effects we observed in this study require further investigation before the full influence of milk protein retentate can be determined at the intestinal colon cell level.

\section{CONCLUSIONS}

Our study combines the identification of bioactive peptides by both a peptidomic and a proteomic approach with in vitro bioactivities evaluated after simulated digestion. In summary, our data show that whey proteins have the highest ACE1-I activity. Further, we found that after in vitro digestion whey proteins generate functional peptides that are preserved, in particular those related to the ACE1-I effect. This makes it possible to hypothesize that whey proteins could have a similar effect in vivo. Casein and soy proteins have stimulatory effects on cell metabolic activity in undifferentiated HT29-MTX-E12 cells, and, in particular, we found that CNP may promote mucus-related gene expression in differentiated HT29-MTX-E12 cells. Furthermore, because whey, $\mathrm{CN}$, and soy are effective in quite low concentrations, they may be useful as functional food ingredients for the treatment of gut injury caused by inflammatory bowel diseases or diarrhea in newborn mammals.

\section{ACKNOWLEDGMENTS}

The authors acknowledge European Joint Doctorate in Molecular Animal Nutrition (MANNA Project) that supports research activities of the PhD student Tamil Selvi Sundaram.

\section{REFERENCES}

Aletti, F., E. Maffioli, A. Negri, M. H. Santamaria, F. A. De Lano, E. B. Kistler, G. W. Schmid-Schönbein, and G. Tedeschi.
2016. Peptidomic analysis of rat plasma: Proteolysis in hemorrhagic shock. Shock 45:540-554. https://doi.org/10.1097/SHK .0000000000000532 .

Baldi, A., I. Politis, C. Pecorini, E. Fusi, R. Chronopoulou, and V. Dell'Orto. 2005. Biological effects of milk proteins and their peptides with emphasis on those related to the gastrointestinal ecosystem. J. Dairy Res. 72:66-72. https://doi.org/10.1017/ S002202990500110X.

Calabrese, E. J., and L. A. Baldwin. 2002. Defining hormesis. Hum. Exp. Toxicol. 21:91-97.

Cheli, F., C. Giromini, and A. Baldi. 2015. Mycotoxin mechanisms of action and health impact: 'in vitro' or 'in vivo' tests, that is the question. World Mycotoxin J. 8:573-589. https://doi.org/10.3920/ WMJ2014.1864.

Clausen, M. R., L. H. Skibsted, and J. Stagsted. 2009. Characterization of major radical scavenger species in bovine milk through size exclusion chromatography and functional assays. J. Agric. Food Chem. 57:2912-2919. https://doi.org/10.1021/jf803449t.

Coccetti, P., F. Tripodi, G. Tedeschi, S. Nonnis, O. Marin, S. Fantinato, C. Cirulli, M. Vanoni, and L. Alberghina. 2008. The CK2 phosphorylation of catalytic domain of Cdc34 modulates its activity at the G1 to S transition in Saccharomyces cerevisiae. Cell Cycle 7:1391-1401. https://doi.org/10.4161/cc.7.10.5825.

Dell'Orco, M.,, P. Milani, L. Arrigoni, O. Pansarasa, V. Sardone, E. Maffioli, F. Polveraccio, M. Bordoni, L. Diamanti, M. Ceroni, F. A. Peverali, G. Tedeschi, and C. Cereda. 2016. Hydrogen peroxidemediated induction of SOD1 gene transcription is independent from Nrf2 in a cellular model of neurodegeneration. Biochim. Biophys. Acta. 1859:315-323. https://doi.org/10.1016/j.bbagrm.2015 .11.009.

Di Pierro, G., M. B. O'Keeffe, A. Poyarkov, G. Lomolino, and R. J. FitzGerald. 2014. Antioxidant activity of bovine casein hydrolysates produced by Ficus carica L.-derived proteinase. Food Chem. 156:305-311. https://doi.org/10.1016/j.foodchem.2014.01.080.

Fekete, Á. A., C. Giromini, Y. Chatzidiakou, D. I. Givens, and J. A. Lovegrove. 2018. Whey protein lowers systolic blood pressure and Ca-caseinate reduces serum TAG after a high-fat meal in mildly hypertensive adults. Sci Rep. 8:5026. https://doi.org/10.1038/ s41598-018-23333-2.

Fekete, Á. A., C. Giromini, Y. Chatzidiakou, D. I. Givens, and J. A. Lovegrove. 2016a. Whey protein lowers blood pressure and improves endothelial function and lipid biomarkers in adults with prehypertension and mild hypertension: Results from the chronic Whey2Go randomized controlled trial. Am. J. Clin. Nutr. 104:1534-1544. https://doi.org/10.3945/ajcn.116.137919.

Fekete, Á. A., D. I. Givens, and J. A. Lovegrove. 2016b. Can milk proteins be a useful tool in the management of cardiometabolic health? An updated review of human intervention trials. Proc. Nutr. Soc. 75:328-341. https://doi.org/10.1017/S0029665116000264.

Fernández-Tomé, S., J. Sanchón, I. Recio, and B. Hernández-Ledesma. 2018. Transepithelial transport of lunasin and derived peptides: Inhibitory effects on the gastrointestinal cancer cells viability. J. Food Compos. Anal. 68:101-110. https://doi.org/10.1016/j.jfca 2017.01.011.

Fusi, E., C. Giromini, R. Rebucci, L. Pinotti, V. Caprarulo, F. Cheli, F. Vitari, C. Domeneghini, and A. Baldi. 2018. Ochratoxin A cytotoxicity on Madin-Darby canine kidney cells in the presence of alpha-tocopherol: Effects on cell viability and tight junctions. J. Anim. Physiol. Anim. Nutr. (Berl.) 102:350-355.

Giromini, C., A. Baldi, E. Fusi, R. Rebucci, and S. Purup. 2015. Effect of growth factors, estradiol $17-\beta$, and short chain fatty acids on the intestinal HT29-MTX cells: Growth factors and SCFAs effects on intestinal E12 cells. Cell Biol. Toxicol. 31:199-209. https://doi .org/10.1007/s10565-015-9304-y.

Giromini, C., F. Cheli, R. Rebucci, and A. Baldi. 2019. Invited review: Dairy proteins and bioactive peptides: Modeling digestion and the intestinal barrier. J. Dairy Sci. 102:929-942.

Giromini, C., Á. A. Fekete, D. I. Givens, A. Baldi, and J. A. Lovegrove. 2017. Short communication: A comparison of the in vitro angiotensin-1-converting enzyme inhibitory capacity of dairy and 
plant protein supplements. Nutrients 9:1352. https://doi.org/10 $.3390 /$ nu9121352.

Giromini, C., R. Rebucci, E. Fusi, L. Rossi, F. Saccone, and A. Baldi. 2016. Cytotoxicity, apoptosis, DNA damage and methylation in mammary and kidney epithelial cell lines exposed to ochratoxin A. Cell Biol. Toxicol. 32:249-258. https://doi.org/10.1007/s10565 $-016-9332-2$

Hartmann, R., and H. Meisel. 2007. Food-derived peptides with biological activity: From research to food applications. Curr. Opin. Biotechnol. 18:163-169. https://doi.org/10.1016/j.copbio.2007.01 .013 .

Iametti, B. S., G. Tedeschi, E. Oungre, and F. Bonomi. 2001. Primary structure of kappa-casein isolated from mares' milk. J. Dairy Res. 68:53-61.

Livak, K. J., and T. D. Schmittgen. 2001. Analysis of relative gene expression data using real-time quantitative PCR and the 2(-Delta Delta $\mathrm{C}(\mathrm{T})$ ) method. Methods 25:402-408. https://doi.org/10 1006 /meth.2001.1262.

Maffioli, E., S. Nonnis, R. Angioni, F. Santagata, B. Calì, L. Zanotti, A. Negri, A. Viola, and G. Tedeschi. 2017. Proteomic analysis of the secretome of human bone marrow-derived mesenchymal stem cells primed by pro-inflammatory cytokines. J. Proteomics 166:115-126. https://doi.org/10.1016/j.jprot.2017.07.012.

Martínez-Maqueda, D., B. Miralles, E. Cruz-Huerta, and I. Recio. 2013. Casein hydrolysate and derived peptides stimulate mucin secretion and gene expression in human intestinal cells. Int. Dairy J. 32:13-19. https://doi.org/10.1016/j.idairyj.2013.03.010.

Martínez-Maqueda, D., B. Miralles, S. De Pascual-Teresa, I. Reverón, R. Muñoz, and I. Recio. 2012a. Food-derived peptides stimulate mucin secretion and gene expression in intestinal cells. J. Agric. Food Chem. 60:8600-8605. https://doi.org/10.1021/jf301279k.

Martínez-Maqueda, D., B. Miralles, I. Recio, and B. Hernández-Ledesma. 2012b. Antihypertensive peptides from food proteins: A review. Food Funct. 3:350-361. https://doi.org/10.1039/c2fo10192k.

Meisel, H., and R. J. FitzGerald. 2003. Biofunctional peptides from milk proteins: Mineral binding and cytomodulatory effects. Curr. Pharm. Des. 9:1289-1295. https://doi.org/10.2174/ 1381612033454847.

Minekus, M., M. Alminger, P. Alvito, S. Ballance, T. Bohn, C. Bourlieu, F. Carrière, R. Boutrou, M. Corredig, D. Dupont, C. Dufour L. Egger, M. Golding, S. Karakaya, B. Kirkhus, S. Le Feunteun, U. Lesmes, A. Macierzanka, A. Mackie, S. Marze, D. J. McClements, O. Ménard, I. Recio, C. N. Santos, R. P. Singh, G. E. Vegarud, M. S. J. Wickham, W. Weitschies, and A. Brodkorb. 2014. A standardised static in vitro digestion method suitable for food-An international consensus. Food Funct. 5:1113-1124. https://doi.org/ $10.1039 / \mathrm{c} 3 f \circ 60702 \mathrm{j}$.

Miner-Williams, W. M., B. R. Stevens, and P. J. Moughan. 2014. Are intact peptides absorbed from the healthy gut in the adult human? Nutr. Res. Rev. 27:308-329. https://doi.org/10.1017/ S0954422414000225.

Minkiewicz, P., J. Dziuba, A. Iwaniak, M. Dziuba, and M. Darewicz. 2008. BIOPEP database and other programs for processing bioactive peptide sequences. J. AOAC Int. 91:965-980.

Mukhopadhya, A., N. Noronha, B. Bahar, M. T. Ryan, B. A. Murray, P. M. Kelly, I. B. O'Loughlin, J. V. O'Doherty, and T. Sweeney 2015. The anti-inflammatory potential of a moderately hydrolysed casein and its $5 \mathrm{kDa}$ fraction in in vitro and ex vivo models of the gastrointestinal tract. Food Funct. 6:612-621.

Nielsen, D. S. G., B. B. Jensen, P. K. Theil, T. S. Nielsen, K. E. B. Knudsen, and S. Purup. 2018. Effect of butyrate and fermentation products on epithelial integrity in a mucus-secreting human colon cell line. J. Funct. Foods 40:9-17. https://doi.org/10.1016/ j.jff.2017.10.023.

Pecorini, C., R. Rebucci, S. Truchet, and A. Baldi. 2009. In vitro effects of lactoferrin on intestinal and mammary epithelial cell lines. Ital. J. Anim. Sci. 8:643-645. https://doi.org/10.4081/ijas.2009.s2 .643 .
Petrat-Melin, B., P. Andersen, J. T. Rasmussen, N. A. Poulsen, L. B. Larsen, and J. F. Young. 2015. In vitro digestion of purified $\beta$-casein variants A 1, A 2, B, and I: Effects on antioxidant and angiotensin-converting enzyme inhibitory capacity. J. Dairy Sci. 98:15-26. https://doi.org/10.3168/jds.2014-8330.

Plaisancié, P., R. Boutrou, M. Estienne, G. Henry, J. Jardin, A. Paquet, and J. Léonil. 2015. $\beta$-Casein (94-123)-derived peptides differently modulate production of mucins in intestinal goblet cells. J. Dairy Res. 82:36-46. https://doi.org/10.1017/S0022029914000533.

Plaisancié, P., J. Claustre, M. Estienne, G. Henry, R. Boutrou, A. Paquet, and J. Léonil. 2013. A novel bioactive peptide from yoghurts modulates expression of the gel-forming MUC2 mucin as well as population of goblet cells and Paneth cells along the small intestine. J. Nutr. Biochem. 24:213-221. https://doi.org/10.1016/ j.jnutbio.2012.05.004

Purup, S., S. D. Nielsen, T. T. Le, H. Bertelsen, J. Sørensen, and L. B. Larsen. 2018. Wound healing properties of commercial milk hydrolysates in intestinal cells. Int. J. Pept. Res. Ther. 25:483-491. https://doi.org/10.1007/s10989-018-9692-y.

Purup, S., and T. S. Nielsen. 2012. Cell-based models to test the effects of milk-derived bioactives. Animal 6:423-432. https://doi .org $/ 10.1017 /$ S1751731111002540.

Purup, S., M. Vestergaard, L. O. Pedersen, and K. Sejrsen. 2007. Biological activity of bovine milk on proliferation of human intestinal cells. J. Dairy Res. 74:58-65. https://doi.org/10.1017/ S0022029906002093.

Re, R., N. Pellegrini, A. Proteggente, A. Pannala, M. Yang, and C. Rice-Evans. 1999. Antioxidant activity applying an improved ABTS radical cation decolorization assay. Free Radicals in Biology and Medicine. 26:1231-1237. https://doi.org/10.1016/S0891 $-5849(98) 00315-3$.

Sanchón, J., S. Fernández-Tomé, B. Miralles, B. Hernández-Ledesma, D. Tomé, C. Gaudichon, and I. Recio. 2018. Protein degradation and peptide release from milk proteins in human jejunum. Comparison with in vitro gastrointestinal simulation. Food Chem. 239:486-494. https://doi.org/10.1016/j.foodchem.2017.06.134.

Shimizu, M. 2004. Food-derived peptides and intestinal functions. Biofactors 21:43-47.

Singh, S., K. Chaudhary, S. K. Dhanda, S. Bhalla, S. S. Usmani, A. Gautam, A. Tuknait, P. Agrawal, D. Mathur, and G. P. Raghava. 2016. SATPdb: A database of structurally annotated therapeutic peptides. Nucleic Acids Res. 44:D1119-D1126.

Tonolo, F., M. Sandre, S. Ferro, A. Folda, V. Scalcon, G. Scutari, E. Feller, O. Marin, A. Bindoli, and M. P. Rigobello. 2018. Milk-derived bioactive peptides protect against oxidative stress in a Caco2 cell model. Food Funct. https://doi.org/10.1039/C7fo01646h.

Vermeirssen, V., J. Van Camp, K. Decroos, L. VanWijmelbeke, and W. Verstraete. 2003. The impact of fermentation and in vitro digestion on the formation of angiotensin-I-converting enzyme inhibitory activity from pea and whey protein. J. Dairy Sci. 86:429-438.

Vizcaino, J. A., A. Csordas, N. del-Toro, J. A. Dianes, J. Griss, I. Lavidas, G. Mayer, Y. Perez-Riverol, F. Reisinger, T. Ternent, Q. W. Xu, R. Wang, and H. Hermjakob. 2016. Update of the PRIDE database and its related tools. Nucleic Acids Res. 44: D447-D456. https://doi.org/10.1093/nar/gkv1145.

Volstatova, T., J. Havlik, M. Potuckova, and M. Geigerova. 2016. Milk digesta and milk protein fractions influence the adherence of $L a c$ tobacillus gasseri $\mathrm{R}$ and Lactobacillus casei FMP to human cultured cells. Food Funct. 7:3531-3538.

Zoghbi, S., A. Trompette, J. Claustre, M. E. Homsi, J. Garzón, G. Jourdan, J. Y. Scoazec, and P. Plaisancié. 2006. $\beta$-Casomorphin-7 regulates the secretion and expression of gastrointestinal mucins through a $\mu$-opioid pathway. Am. J. Physiol. Gastrointest. Liver Physiol. 290:G1105-G1113. https://doi.org/10.1152/ajpgi.00455 .2005 . 